\title{
Prevalence and Risk Factors for Chronic Hepatitis B in HIV Patients Attended at a Sexually- Transmitted Disease Clinic in Vitoria, Brazil
}

\author{
Adriana Marchon Zago ${ }^{1}$, Thayla Ferrari Machado ${ }^{2}$, Flavia Lagrota Cazarim ${ }^{2}$ and Angélica Espinosa Miranda ${ }^{2}$ \\ ${ }^{1}$ Reference Center for STI \& AIDS; ${ }^{2}$ Infectious Diseases Unit, Federal University of Espírito Santo;Vitória, ES, Brazil
}

\begin{abstract}
This study assessed the prevalence of and correlated factors for chronic hepatitis B infection (HBV) among HIV patients attending the Reference Center for Sexually Transmitted Infections (STI) and AIDS in Vitória, ES, Brazil. HIV patients were studied from 1993 to 2004, using information recorded in a database of the STI Clinic. Demographic data, clinical characteristics, patterns of risk behavior and test results (ELISA-HIV, IFA-HIV, HBsAg, viral load and CD4 counts) were analyzed. We analyzed 851 HIV patients. Median age was 35.0 (interquartile range $30 ; 42$ ) years and median years of education was 8.0 (IQR 5; 11). The prevalence of chronic HBV was 3.8\% (95\% CI 2.5-5.1). Illicit drug use was reported in $185(21.7 \%)$ cases, alcohol abuse in $80(9.4 \%)$ cases, men who have sex with men in 116 (13.6\%) cases, and past STI in $320(37.6 \%)$ cases. Chronic HBV was associated with intravenous drug use, male gender, STI associated with HIV diagnosis, and death. There is a need for prevention and assistance strategies to control the evolution of this infection in HIV patients.
\end{abstract}

Key-Words: HBV, HIV, prevalence, STI clinic.

Hepatitis B virus (HBV) infection is one of the most common infections in the world, with approximately 2 billion people infected [1]. Approximately five per cent suffer from chronic liver disease [1]. Also, over two-thirds of all cases of liver cancer worldwide are caused by HBV [2]. While chronic$\mathrm{HBV}$ infection in the setting of HIV/AIDS is not considered an opportunistic infection, it is a common co-existing infection seen in HIV-infected individuals because of the shared modes of transmission [3].

HIV-positive individuals, particularly those with suppressed immune systems, are less likely to respond to vaccination against $\mathrm{HBV}$, are at higher risk for antiretroviraltherapy failure and are more likely to develop chronic disease after being exposed to HBV [4,5]. Moreover, individuals coinfected with HBV and HIV more frequently present persistent serological markers, have higher HBV-DNA levels, and experience more severe liver disease as a result of chronic infection [5].

There is little data on the prevalence of co-infection in the Espírito Santo state population. We examined chronic-HBV prevalence and correlated factors among HIV patients. This information will be used for planning prevention and assistance programs for this population.

\section{Materials and Methods}

Setting

The study was performed in Vitória, a port city located in the state of Espírito Santo, in the southeast region of Brazil. Using information recorded in the database of an STI clinic (Reference Center for STI/AIDS), 851 HIV patients were

Received on 8 February 2007; revised 13 August 2007.

Address for correspondence: Dr. Adriana Marchon Zago, MD MSc. Rua Aristobulo Barbosa Leão, 383, 201-A, Jardim da Penha, Vitória, Espirito Santo, Brazil. Zip code: 29060-010. Phone: (55) 27-3227-9231. Fax: 27-3132-5106. E-mail: am-zago@uol.com.br.

The Brazilian Journal of Infectious Diseases 2007;11(5):475-478. (C) 2007 by The Brazilian Journal of Infectious Diseases and Contexto Publishing. All rights reserved. followed in the service from 1993 to 2004 . This STI clinic was the first primary-health-care unit to offer HIV testing for people living in the metropolitan area of Vitória. Patients were either referred by physicians or self-referred to the service. The medical research and ethics committee of the Federal University of Espírito Santo State approved this study.

\section{Data Collection}

During the study period, 18,798 individuals went to the clinic to be tested for HIV; out of these, 925 were HIV positive. HIV patients, tested for HBV, were eligible to participate in this study, giving a total of 851(92\%). Seventy-four records (8.0\%) were not included in this study because there was insufficient information about the patient in the medical records. They had been to the clinic merely to be tested and then either moved to another town, or only wanted a dentist or social service, or they were lost to follow up.

Information extracted from medical records included demographic data (gender, age, schooling, and marital status), clinical characteristics (HIV status, CD4 count at the time of HIV diagnosis, hemophilia, opportunistic infections) and riskbehavior patterns (sexual behavior, number of sexual partners, condom use, history of STI, blood transfusion, alcohol and/ or drug use).

\section{Laboratory Tests}

In the clinical routine, a blood sample was collected for testing for HIV and HBV infection. The following tests were performed: ELISA screening (Cobas Core Anti HIV-1/HIV-2 EIA DAGS, Roche Laboratories), with confirmation by fluorescent antibody for HIV-1 (FIOCRUZ), HBsAg (Imx HbsAg assay, Abbott Laboratories), viral load and CD4 counts. Chronic HBV infection was defined when the patient had a positive HbsAg test.

\section{Data Analysis}

Standard descriptive statistical analysis was performed, including frequency distributions for qualitative data and 
calculation of means, standard deviations, medians and interquartile ranges for continuous variables. Prevalence rates were calculated to determine the relative frequency of each disease, with corresponding 95\% confidence intervals (CI). Odds Ratios (RR) and 95\% CI were calculated in bivariate analyses to estimate the strength of the association between each infection type and potential risk factors. Independent risk factors for HBV infection were assessed using stepwise logistic regression: variables significant at $\mathrm{p}<0.05$ in the bivariate analysis were entered into the model, and additional variables were entered into the multivariate model based on known a priori associations (for instance, age and number of sex partners).

\section{Results}

Among the patients who went to the clinic, 5.5\% were HIV positive. The prevalence rate of chronic HBV infection in HIV patients was 3.8\% (95\%CI 2.5-5.1).

Median age was 35.0 [interquartile range (IQR) 30; 42] years and median years of education was 8.0 (IQR 5; 11). Illicit-drug use was reported in 185 (21.7\%) cases, alcohol abuse in 80 (9.4\%) cases, and men who have sex with men in $116(13.6 \%)$ cases. Mean age at first intercourse was 16.2 $(\mathrm{SD}=3.5)$ and $320(37.6 \%)$ patients reported past STI. Onehundred-sixteen (28.4\%) women were diagnosed for HIV during pregnancy.

At the time of HIV diagnosis, the median CD4 count was 357.0 (IQR 176.50; 549.00) cells/mL and the median viral load was $4.09 \log _{10}$ (IQR 3.42; 4.80) copies/mL. Candidiasis (15.5\%) and tuberculosis (8.5\%) were the most frequent opportunistic infections; $57.6 \%$ of the patients were asymptomatic at the time of diagnosis.

There were significant associations between chronichepatitis-B infection and male gender, STI during the HIV diagnosis and IV drug in the univariate analysis (Table 1). Table 2 shows variables identified in multivariate analyses found to be independently associated with chronic HBV infection. Male gender, death, STI during HIV diagnosis and IV drug use were significantly associated with HBV infection. Participant age was dropped from the model, as it had no independent association with HBV. This had no effect on the risk estimates of the other variables in the model.

\section{Discussion}

Our study was designed to assess the prevalence of and correlated factors for chronic hepatitis B infection (HBV) among HIV patients attending the Reference Center for STI and AIDS in Vitória, Brazil. HBV prevalence was 3.8\% in HIV patients. Other studies performed in Brazil found prevalence rates ranging from $5.7 \%$ to $24.3 \%$ [6-10], and other Latin-America and European studies reported prevalences from 7.9 to $17.0 \%$ [11-14].

Previous studies performed on other populations in this same metropolitan area reported prevalence rates of $1.1 \% \mathrm{HBV}$ carriers in pregnant women $[15,16], 5.4 \%$ in women who were attended at an STI clinic [17], and 7.9\% in HIV patients attended at a university hospital [18].

In our study, the median age was 35 years, with a median of eight years education. These data are similar to those reported for Brazilian cases of AIDS published by the national AIDS program [19]. There was no difference in HBV frequency between genders (52.1\% x 47.9\%), although male HIV-positive patients were three times more likely to have chronic HBV than HIV-positive women. Other studies also reported a higher frequency of HBV among men [11,14,20].

Regarding AIDS diagnoses, AIDS-defining illnesses, baseline CD4 cell count and viral load were not significantly different between HBV-positive and HBV-negative patients. These data are in agreement with other studies that did not find a difference between these two groups [21-23]. Konopnicki et al. found differences between the two groups, but this was not the case among new AIDS cases [14].

In our study, the frequency of HBsAg was significantly higher in IV drug users. Drug use is an important route of transmission of HBV [24]. In Argentina, De los Angeles found that injectable drug-related and sexual transmission of hepatitis viruses are a significant problem among young, HIV-infected, and heterosexual individuals [11]. Fainboim found a higher frequency of HbsAg among IV drug users than among heterosexual patients [12]. Trepka et al. found an association between HBV and IV drug use in patients attending an STI clinic in Miami, USA [26]. Although some studies showed associations among HBV, HIV and homosexuality [24-26], this association was not found in our study. One reason that could explain the lack of association was the number of people (112 among 443 male patients) that reported this practice.

The modest sample size, the unique nature of the sample and the fact that it is a retrospective study could limit inference for other similar HIV patients in the city. However, the clinic receives almost all patients in the municipality and the low lost of accessing records are strengths that could outweigh this potential limitation. The possibility of response bias, due to the tendency to provide socially-acceptable responses, cannot be excluded. Inaccuracies of recall about condom use, age of first intercourse and number of sexual partners also may have occurred.

Among HBV-negative patients, prevention programs can successfully implement confidential services for counseling and immunization to avoid infection. In 1993, immunization was offered to children up to five years and health professionals in the Espírito Santo State endemic area. After 1997, this was extended to all children up to 12 years [27]. Young people and health professionals receive immunization from the government. Currently, it is necessary to implement a system offering vaccines to vulnerable populations, such as illicit drug users, sex professionals, HIV patients and homosexuals.

Data about chronic HBV infection in HIV patients are important to identify the profile of these individuals and direct 
Table 1. Socio-demographic, behavioral and clinical characteristics of HIV patients according to HBV status in Vitória, Brazil

\begin{tabular}{|c|c|c|c|}
\hline Variable & $\begin{array}{c}\text { HBsAg positive (32) } \\
\text { N (\%) }\end{array}$ & $\begin{array}{c}\text { HBsAg negative (819) } \\
\text { N (\%) }\end{array}$ & OR (95\%CI) \\
\hline \multicolumn{4}{|l|}{ Gender } \\
\hline Male & $25(5.6)$ & $418(94.4)$ & \multirow[t]{2}{*}{$3.4(1.46-8.01)$} \\
\hline Female & 7 (1.7) & 401 (98.3) & \\
\hline \multicolumn{4}{|l|}{ Education } \\
\hline Up to 4 years & $6(3.5)$ & 177 (96.7) & \multirow{2}{*}{$1.2(0.48-2.94)$} \\
\hline More than 4 years & $26(3.8)$ & $642(96.1)$ & \\
\hline \multicolumn{4}{|l|}{ Sexual behavior } \\
\hline Heterosexual & $21(5.4)$ & $626(94.6)$ & \multirow[t]{2}{*}{$1.9(0.89-4.05)$} \\
\hline Homo/bisexual & $11(3.8)$ & $193(96.2)$ & \\
\hline \multicolumn{4}{|l|}{ Sexual partners } \\
\hline Only one partner & $12(2.7)$ & 428 (97.3) & \multirow[t]{2}{*}{$0.8(0.39-1.68)$} \\
\hline More than one & $20(4.8)$ & 39 (95.1) & \\
\hline \multicolumn{4}{|l|}{ Condom use } \\
\hline Regular use & $2(2.3)$ & $84(97.7)$ & \multirow[t]{2}{*}{$0.6(0.14-2.48)$} \\
\hline Rarely/never use & $30(3.9)$ & 735 (96.1) & \\
\hline \multicolumn{4}{|l|}{ Past STI } \\
\hline Yes & $10(3.1)$ & 310 (96.9) & \multirow[t]{2}{*}{$1.4(0.65-3.03)$} \\
\hline No & $22(4.1)$ & 509 (95.9) & \\
\hline \multicolumn{4}{|l|}{ STI at HIV diagnosis } \\
\hline Yes & $17(6.6)$ & $241(93.4)$ & \multirow[t]{2}{*}{$2.3(1.11-4.70)$} \\
\hline No & $15(2.5)$ & 578 (97.5) & \\
\hline \multicolumn{4}{|l|}{ Blood transfusion } \\
\hline Yes & $2(3.0)$ & $65(97.0)$ & \multirow[t]{2}{*}{$2.5(0.37-20.00)$} \\
\hline No & $30(3.8)$ & 754 (96.2) & \\
\hline \multicolumn{4}{|l|}{ IV drug use } \\
\hline Yes & $16(8.6)$ & 169 (91.4) & \multirow[t]{2}{*}{$4.6(2.13-9.94)$} \\
\hline No & $16(2.4)$ & $650(97.6)$ & \\
\hline \multicolumn{4}{|l|}{ AIDS symptoms } \\
\hline Yes & $12(3.6)$ & 323 (96.4) & \multirow[t]{2}{*}{$1.1(0.52-2.27)$} \\
\hline No & 20 (3.9) & 496 (96.1) & \\
\hline \multicolumn{4}{|l|}{ CD4 count } \\
\hline$\leq 200$ & $8(4.6)$ & $165(95.4)$ & \multirow[t]{2}{*}{$1.3(0.58-2.99)$} \\
\hline$>200$ & $24(3.5)$ & 654 (96.5) & \\
\hline \multicolumn{4}{|l|}{ Death during follow up } \\
\hline Yes & 4 (14.3) & 24 (85.7) & \multirow[t]{2}{*}{$4.7(1.54-14.54)$} \\
\hline No & $28(3.4)$ & 795 (96.6) & \\
\hline \multicolumn{4}{|l|}{ HCV positive } \\
\hline Yes & $6(7.7)$ & 72 (92.3) & \multirow[t]{2}{*}{$2.4(0.95-6.00)$} \\
\hline No & $26(3.4)$ & 747 (96.6) & \\
\hline
\end{tabular}

Table 2. Multivariate analysis of factors independently associated with HBV among HIV patients in Vitória, ES, Brazil

\begin{tabular}{lccc}
\hline Variables & OR & $\mathbf{9 5 \% ~ C I ~}$ & pvalue \\
\hline Male gender & 2.9 & $1.06-7.96$ & 0.0386 \\
Death & 4.0 & $1.11-14.08$ & 0.0335 \\
STI at HIV diagnosis & 2.7 & $1.18-6.08$ & 0.0184 \\
IV drug use & 3.5 & $1.38-9.06$ & 0.0084 \\
\hline
\end{tabular}

Overall percentage of total data used in the analysis due to listwise deletion was 96.18. Hosmer and Lomeshow Test: 0.4379 . OR=odds ratio. $\mathrm{CI}=$ confidence interval. 
prevention and assistance strategies. Evidence of higher prevalence of HBV among HIV-positive patients, mainly among IV drug users, reinforces the need for including counseling in educational programs in an effort to decrease the incidence of multiple infections [8]. The prevention of HBV transmission depends in part on identifying people who are HBV infected, and providing counseling about reducing the risk of transmission to others, delivering medical care and antiviral therapy that could lower infectivity, and vaccinating sexual and needle-sharing partners.

\section{References}

1. WHO Report: 1996: fighting disease, fostering development. Geneva: World Health Organization; 1996.

2. Lee W.M. Hepatitis B virus infections. $N$ Engl J Med 1997;337:1733-45.

3. Thio C.L. Hepatitis B in the human immunodeficiency virusinfected patient: epidemiology, natural history, and treatment. Semin Liver Dis 2003;23:125-36.

4. Ockenga J., Tillmann H.L., Trautwein C., et al. Hepatitis B and C in HIV-infected patients. Prevalence and prognostic value. J Hepatol 1997;27(1):18-24.

5. Nunez M., Soriano V. Management of patients co-infected with hepatitis B virus and HIV. Lancet Infect Dis 2005;5(6):374-82.

6. Mendes-Correa M.C., Barone A.A., Cavalheiro N., et al. Prevalence of hepatitis B and C in the sera of patients with HIV infection in Sao Paulo, Brazil. Rev Inst Med Trop Sao Paulo 2000;42(2):81-5.

7. Santos E.A., Yoshida C.F., Rolla V.C., et al. Frequent occult hepatitis $B$ virus infection in patients infected with human immunodeficiency virus type 1. Eur J Clin Microbiol Infect Dis 2003;22(2):92-8.

8. Treitinger A., Spada C., Silva E.L., et al. Prevalence of Serologic Markers of HBV and HCV Infection in HIV-1 Seropositive Patients in Florianopolis, Brazil. Braz J Infect Dis 1999;3(1):1-5.

9. Braga W.S.M., Castilho M.C., Santos I.C.V., et al. Baixa prevalência do vírus da hepatite $\mathrm{B}$, vírus da hepatite $\mathrm{D}$ e vírus da hepatite $\mathrm{C}$ entre pacientes com o vírus da imunodeficiência humana ou síndrome da imunodeficiência adquirida na Amazônia Brasileira. Rev Soc Bras Med Trop 2006;39(6):519-522.

10. Souza M.G., Passos A.D., Machado A.A., et al. HIV and hepatitis B virus co-infection: prevalence and risk factors. Rev Soc Bras Med Trop 2004;37(5):391-5.

11. De los Angeles Pando M., Biglione M.M., Toscano M.F., et al. Human immunodeficiency virus type 1 and other viral coinfections among young heterosexual men and women in Argentina. Am J Trop Med Hyg 2004 Aug;71(2):153-9.

12. Fainboim H., Gonzalez J., Fassio E., et al. Prevalence of hepatitis viruses in an anti-human immunodeficiency virus-positive population from Argentina. A multicentre study. J Viral Hepat 1999;6(1):53-7.
13. Juarez-Figueroa L.A., Uribe-Salas F.J., Conde-Glez C.J., et al. Hepatitis B markers in men seeking human immunodeficiency virus antibody testing in Mexico City Sex Transm Dis 1997;24(4):211-7.

14. Konopnicki D., Mocroft A., de Wit S., et al. Hepatitis B and HIV: prevalence, AIDS progression, response to highly active antiretroviral therapy and increased mortality in the Europe. AIDS 2005;19(6):593-601.

15. Miranda A.E., Alves M.C., Neto R.L., et al. Seroprevalence of HIV, HBV and syphilis in women ot their first visit to public antenatal clinics in Vitória, Brazil. Sex Transm Dis 2001;28(12);710-714

16. Lima L.H.M. Prevalência e fatores de risco para infecção por HIV, sífilis, hepatite B, hepatite C e infecção por HTLV-I/II em parturientes e gestantes de baixa renda atendidas na região metropolitana de Vitória. Masters degree thesis, Infectious diseases program of Universidade Federal do Espírito Santo. Vitória, 2003.128p.

17. Miranda A.E., Nogueira E.G., Ribeiro E.S. Soroprevalência de HBSAG positivo entre mulheres atendidas em clínica de doenças sexualmente transmissíveis. Jornal Brasileiro de Doenças Sexualmente Transmissíveis 1999;11:22-5.

18. Reuter T., Gonçalves F.L., Tose S.F.C., et al. Estudo de Prevalência da Co-Infecção HIV/Vírus B e C da Hepatite em Vitória-ES. Presented as a poster at the XI Congresso Brasileiro de Infectologia. São Paulo, 1999.

19. Brasil. Ministério da Saúde. Secretaria de Vigilância em saúde. Programa Nacional de DST e AIDS. Boletim Epidemiológico AIDS e DST. Ano I, n ${ }^{\circ} 1,1^{\text {a }}$ a $26^{\text {a }}$ semanas epidemiológicas de 2004, 2005.

20. Uneke C.J., Ogbu O., Inyama P.U., et al. Prevalence of hepatitisB surface antigen among blood donors and human immunodeficiency virus-infected patients in Jos, Nigeria. Mem Inst Oswaldo Cruz 2005;100(1):13-6.

21. Lincoln D., Petoumenos K., Dore G.J., Australian HIV Observational Database. HIV/HBV and HIV/HCV co-infection, and outcomes following highly active antiretroviral therapy. HIV Med 2003;4(3):241-9.

22. Thio C.L., Seaberg E.C., Skolasky R. Jr., et al. HIV-1, hepatitis B virus, and risk of liver-related mortality in the Multicenter Cohort Study (MACS). Lancet 2002;14;360(9349):1921-6.

23. Sinicco A., Raiteri R., Sciandra M., et al. Co-infection and superinfection of hepatitis B virus in patients infected with human immunodeficiency virus: no evidence of faster progression to AIDS. Scand J Infect Dis 1997;29(2):111-5.

24. Koblin B.A., Torian L.V., Guilin V., et al. High prevalence of HIV infection among young men who have sex with men in New York City. AIDS. 2000Aug 18;14(12):1793-800.

25. Choi K.H., McFarland W., Neilands T.B., et al. High level of hepatitis B infection and ongoing risk among Asian/Pacific Islander men who have sex with men, San Francisco, 20002001. Sex Transm Dis 2005;32(1):44-8.

26. Trepka M.J., Weisbord J.S., Zhang G., Brewer T. Hepatitis B virus infection risk factors and immunity among sexually transmitted disease clinic clients. Sex Transm Dis 2003;30(12):914-8.

27. Brasil. Ministério da Saúde. Portaria No 263/02 GM - Ministério da Saúde, 05/02/2002. www.saude.gov.br/sps/areastecnicas/hepatite/ Accessed 29/08/05. 